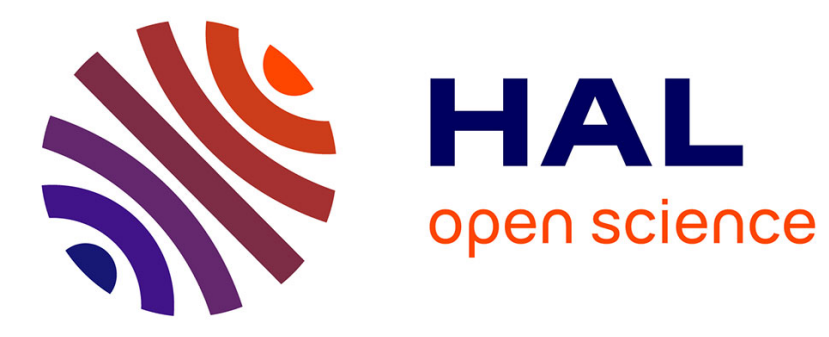

\title{
Stay true to integrated pest management
}

Kris Wyckhuys, Francisco Sanchez-Bayo, Alexandre Aebi, Maarten Bijleveld van Lexmond, Jean-Marc Bonmatin, Dave Goulson, Edward Mitchell

\section{To cite this version:}

Kris Wyckhuys, Francisco Sanchez-Bayo, Alexandre Aebi, Maarten Bijleveld van Lexmond, Jean-Marc Bonmatin, et al.. Stay true to integrated pest management. Science, 2021, 371 (6525), pp.133.1-133. 10.1126/science.abf8072 . hal-03106280

\section{HAL Id: hal-03106280 \\ https://hal.science/hal-03106280}

Submitted on 13 Oct 2021

HAL is a multi-disciplinary open access archive for the deposit and dissemination of scientific research documents, whether they are published or not. The documents may come from teaching and research institutions in France or abroad, or from public or private research centers.
L'archive ouverte pluridisciplinaire HAL, est destinée au dépôt et à la diffusion de documents scientifiques de niveau recherche, publiés ou non, émanant des établissements d'enseignement et de recherche français ou étrangers, des laboratoires publics ou privés. 


\section{Stay true to integrated pest management}

Kris Wyckhuys ${ }^{1,2,3 *}$, Francisco Sanchez-Bayo ${ }^{4}$, Alexandre Aebi ${ }^{5}$, Maarten Bijleveld van Lexmond ${ }^{6}$, Jean-Marc Bonmatin ${ }^{7}$, Dave Goulson ${ }^{8}$, Edward Mitchel| ${ }^{5,9}$

IInstitute of Plant Protection, China Academy of Agricultural Sciences, Beijing, China. ${ }^{2}$ University of Queensland, Brisbane, QLD, Australia. ${ }^{3}$ Chrysalis Consulting, Hanoi, Vietnam. ${ }^{4}$ University of Sydney, Sydney, NSW, Australia. ${ }^{5}$ University of Neuchatel, Neuchatel, Switzerland. IInternational Union for Conservation of Nature Task Force on Systemic Pesticides, Neuchatel, Switzerland.

${ }^{7}$ Centre de Biophysique Moléculaire, Centre

National de la Recherche Scientifique, Orléans,

France. ${ }^{8}$ University of Sussex, Brighton, UK.

${ }^{9}$ Botanical Garden of Neuchatel, Neuchatel,

Switzerland.

*Corresponding author.

Email: kagwyckhuys@gmail.com

On 2 October 2020, the United Nations Food and Agriculture Organization (FAO) and CropLife International signed a letter of intent to establish a strategic partnership (1). Moving forward, CropLife International's aspirations should be closely scrutinized. Checks and balances are essential to ensure that private interests do not take precedence over the common good.

For decades, both the FAO and CropLife International have advocated the uptake of integrated pest management-an approach that strategically integrates different crop protection methods to safeguard crop yields, secure farmer livelihoods, and preserve natural capital (2). However, their respective interpretations of the system's core constituents, underlying principles, and ultimate goals differ substantially. The FAO emphasizes how preventing pests through good agronomy, biological diversity, and ecological processes can lower the amount of pesticide required, whereas CropLife International focuses on the responsible use of agrochemicals, with far less desirable results.

The FAO's interpretation of integrated pest management has led to successes worldwide. Its Farmer Field Schools have transferred ecological concepts and nonchemical technologies to millions of small farmers, resulting in pesticide reductions of $92 \%$ in Bangladesh rice, $78 \%$ in India cotton, and $61 \%$ in Vietnamese tea (3). These FAO programs have attained pesticide cuts of 50 to $80 \%$ on millions of farms without yield loss (4), thus lifting farmers' profits, curbing energy use, and bolstering rural economies (5). Unfortunately, when some programs were dismantled in the mid-1990s, achievements were rapidly undone (6); Indonesia's pesticide use has since risen substantially.
Meanwhile, Croplife International's approach-i.e., pesticide-centered controlcontinues to proliferate across the globe $(7$, 8 ). For example, insecticide-coated seeds are zealously backed by chemical enterprises (9), even though their on-farm use violates integrated pest management principles, triggers resistance development, exacerbates pollution, and degrades the resilience of farmland ecosystems (10). By thus deviating from established decision-making criteria and tolerating technology integration that occurs by chance instead of by design, this approach leads to ineffective pest control and negative social-ecological outcomes (11). Agro-ecology, digital tools, and innovative farming schemes can all remediate chemical dependencies, but agro-industry meddling constitutes a prominent hurdle (12).

Ultimately, globe-spanning alliances that include agro-industry should only be built to scale up environmentally compatible practices and to pursue agri-food system transformations that are protective of human and environmental health. In the spirit of integrated pest management, as correctly interpreted and implemented by the FAO, biodiversity and ecological safeguards should constitute plant health programs' first line of defense, whereas pesticide use needs to be consciously downgraded to a measure of last resort.

\section{REFERENCES AND NOTES}

1. "Letter of intent between the Food and Agriculture Organization of the United Nations and CropLife International" (2020); www.fao.org/fileadmin/user upload/newsroom/docs/CropLife.pdf.

2. S. E. Naranjo, J. Agric. Food Chem. 59, 11(2011).

3. H. van den Berg, J. Jiggins, World Dev. 35, 4 (2007).

4. D. G. Bottrell, K. G. Schoenly, J. Asia Pac. Entomol. 15 1(2012).

5. H. Waddington et al., Campbell Systemat. Rev. 10 , 1(2014).

6. C. Thorburn, Agroecol. Sustain. Food Syst. 38,3 (2014)

7. E. S. Bernhardt et al., Front. Ecol. Environ. 15,2 (2017).

8. P.J. Landrigan et al., Lancet 391,10119 (2018).

9. C. Hitaj et al.,BioScience 70,5(2020).

10. G. Labrie et al.,PLOS ONE 15, 2 (2020)

11. L.P.Pedigo, M. E. Rice, Entomology and Pest Management (Waveland Press, 2014).

12. D. Goulson, One Earth 2, 4 (2020). 